\title{
Perbandingan Kemampuan Pemahaman Matematis Antara Siswa yang Mendapatkan Pembelajaran Investigasi Kelompok dengan Pembelajaran Ekspositori
}

\author{
Vici Suciawati ${ }^{1}$ \\ 1Pendidikan Matematika, Universitas Majalengka \\ email: vicisuciawati@unma.ac.id
}

\begin{abstract}
Abstrak-Siswa mempunyai karakteristik yang beragam, seorang siswa dapat menempuh pembelajaran secara lancer dan berhasil tanpa memperoleh hambatan, sedangkan tidak sedikit juga yang mengalami kesulitan dalam proses pembelajaran. Pada penelitian ini yang menjadi pertanyaan penelitiannya adalah "apakah terdapat perbedaan pemahaman matematis siswa antara yang pembelajarannya metode investigasi kelompok dengan metode ekpositori?". Penelitian ini menggunakan metode quasi eksperimen dengan sampel penelitian kelas VIIIE sebagai kelas eksperimen dan VIIID kelas kontrol. Berdasarkan analisis data penelitian pada kelas yang mendapatkan pembelajaran dengan metode investigasi kelompok diperoleh kenaikan rata-rata tes awal dan akhir yang cukup signifikan, sedangkan kenaikan rata-rata tes awal dan akhir yang mendapatkan pembelajaran metode ekspositori tidak signifikan. Artinya pembelajaran dengan metode investigasi kelompok lebih baik di bandingkan dengan metode ekspositori.
\end{abstract}

Kata kunci: Metode Invetigasi Kelompok, Metode Ekspositori, Pemahaman Matematis 


\section{PENDAHULUAN}

Proses pembelajaran merupakan suatu proses sosial yang terjadi ketika masing-masing orang berhubungan dengan yang lain dan membangun pengertian dan pengetahuan bersama. Belajar dimaknai sebagai proses perubahan perilaku sebagai hasil interaksi individu dengan lingkungannya, perubahan perilaku terhadap hasil belajar bersifat continiu, fungsional, positif, aktif, dan terarah, proses perubahan tingkah laku dapat terjadi dalam berbagai kondisi berdasarkan penjelasan dari para ahli pendidikan dan psikologi (Pane \& Dasopang, 2017). Proses pendidikan merupakan suatu proses sosial yang tidak dapat terjadi tanpa adanya interaksi antar pribadi. Hal yang terpenting pada proses tersebut adalah kesadaran bahwa setiap siswa memiliki karakteristik yang beragam, sehingga ini berdampak pada proses pembelajaran di kelas. Jadi dikatakan berhasil suatu proses pembelajaran di kelas jika terjadi perubahan perilaku positif siswa dalam kehidupannya (M Gilar Jatisunda, 2017)

Pada umumnya, siswa di setiap jenjang pendidikan, mulai pendidikan dasar sampai perguruan tinggi merasa cemas ketika berhadapan dengan mata pelajaran matematika, banyak orang dewasa, baik mereka yang berhubungan dengan matematika maupun yang tidak bekerja pada ranah yang memerlukan matematika merasa cemas ketika mereka dihadapkan dengan matematika (Yuliani, 2017). Matematika juga merupakan "kendaraan" utama untuk mengembangkan kemampuan berpikir logis dan keterampilan kognitif yang lebih tinggi pada anak-anak (Sutrisno, 2015). Proses pembelajaran di kelas perlu memperhatikan keberagaman siswa, supaya tidak berdampak pada kesulitan-kesulitan siswa ketika mengalami proses pembelajaran. Kurangnya pemanfaatan waktu yang telah diberikan oleh guru untuk mempertanyakan mengenai materi yang kurang di mengerti sehingga siswa kesulitan untuk menyelesaikan masalah sehingga siswa lebih senang apabila guru yang menyelesaikan soal (Putridayani \& Chotimah, 2020). Kesulitan belajar yang di alami oleh siswa dapat bersifat psikologis, sosiologis, dan fisiologis sehingga bisa berdampak pada proses pemahaman matematis siswa terkait dengan konsep matematika yang di pelajarinya.

Pemahaman bukan hanya mengetahui suatu informasi, melainkan lebih dari itu siswa dapat memaknai dan mentransformasi suatu informasi tersebut kedalam wujud lain yang lebih berarti, sehingga dapat membantu siswa dalam pemecahan masalah matematika yang lebih sulit (Mohamad Gilar Jatisunda, 2019). Pemahaman bukanlah semata-mata memahami informasi akan tetapi siswa dapat mengartikan lalu mengubah subuah informasi yang difikirkan kedalam suatu bentuk lain, sehingga siswa dapat terbantu dalam memecahkan masalah lain yang kian sulit (Kamalia, Basir, \& Ubaidah, 2020). Kemampuan pemahaman merupakan salah satu Power math atau kekuatan matematis (Rijanto, 2020). Pemahaman mempengaruhi kepercayaan siswa selalu akan memunculkan pengetahuan-pengetahuan yang saling berhubungan secara sistematis dalam struktur kognitif (Hasanah, 2004). Ada tujuh aspek yang termuat dalam kemampuan pemahaman matematis, yaitu menginterpretasikan, memberikan contoh, mengklasifikasikan, merangkum, menduga, membandingkan, dan menjelaskan (Sariningsih, 2014).

Tentunya untuk menumbuhkan sikap aktif dan kreatif dari siswa ketika 
proses pembelajaran diperlukan model pembelajaran yang memfasilitasi hal tersebut. Salah satu alternatif pembelajaran yang menuntut siswa untuk aktif dan kreatif adalah model pembelajaran kooperatif. Paradigrma pembelajaran matematika terus berkembang sehingga pada saat ini pembelajaran matematika menuntut peran aktif siswa yang lebih besar dan guru hanya bersifat sebagai fasilitator pembelajaran.

Artinya guru harus memiliki kreatifitas agar proses pembelajaran bisa berjalan dengan baik dan siswa bisa aktif secara penuh untuk mendapatkan pemahaman matematis terkait konsep yang di pelajarinya. Landasan filosofis pembelajaran kooperatif adalah pandangan filsafat kons- ruktivisme, khususnya yang berkenaan de- ngan proses belajar siswa, proses mengajar guru, dan kondisi pembelajarannya (Anita, 2018). Pembelajaran investigasi kelompok memuat enam tahapan kegiatan dalam proses pembelajaran yaitu tahap pengelompokan, tahap perencanaan, tahap investigasi, tahap pengorganisasian, tahap presentasi, dan tahap evaluasi (Slavin, 1980). Pembelajaran investigasi kelompok memberikan kesempatan kepada masing- masing kelompok untuk mengamati, menganalisis, mendiskusikan, dan me- ngambil kesimpulan (Isjoni, 2013).

\section{METODE PENELITIAN}

Penelitian kuantitatif didasari pada filsafat positivisme yang menekankan fenomena objektif yang dikaji secara kuantitatif atau dilakukan dengan menggunakan angka, pengolahan statistik, struktur, dan percobaan terkontrol (Sukmadinata, 2005). Penelitian eksperimen yaitu penelitian yang digunakan untuk mencari pengaruh perlakuan tertentu terhadap yang lain dalam kondisi yang terkendali (Arikunto \& Jabar, 2004). Sedangkan jenis penelitian yang digunakan pada penelitian ini yaitu penelitian quasi eksperimental design. Cara untuk mengetahuinya yaitu membandingkan satu atau lebih kelompok eksperimen yang diberi treatment dengan satu kelompok pembanding yang tidak diberi treatment.

Quasi experimental design terdapat dua bentuk yaitu time series design dan nonequivalent control group design (Sugiyono, 2006). Desain yang digunakan dalam penelitian ini adalah quasi experimental design dan menggunakan model nonequivalent control group design

Tabel 1. Desain Penelitian nonequivalent control group design

\begin{tabular}{|c|c|c|}
\hline$O_{1}$ & $\mathrm{x}$ & $\mathrm{O}_{2}$ \\
\hline$O_{3}$ & & $O_{4}$ \\
\hline
\end{tabular}

Keterangan:

$O_{1}$ : Pretes kelas eksperimen

$\mathrm{O}_{2}$ : Postes kelas eksperimen

$\mathrm{O}_{3}$ : Pretes kelas kontrol

$\mathrm{O}_{4}$ : Postes kelas kontrol

$X$ : Perlakuan pada kelas eksperimen berupa pembelajaran metode investigasi kelompok.

Variabel Penelitian yaitu suatu atribut atau sifat atau nilai dari orang, objek atau kegiatan yang variasi tertentu yang ditetapkan oleh peneliti untuk dipelajari dan kemudian ditarik kesimpulan (Sugiyono, 2006).

\section{HASIL DAN PEMBAHASAN}

Untuk mengetahui apakah terdapat perbedaan hasil belajar matematika lebih spesifik pemahaman matematis siswa yang pembelajarannya menggunakan meotde investigasi kelompok dengan menggunkan metode ekspositori dengan menggunakan tes tulis yaitu pretes dan postes berupa soal uraian yang 
berjumlah 5 soal. Berikut merupakan deskripsi hasil penelitian:

Tabel 2

Hasil Pretes Kelas Eksperimen

\begin{tabular}{|c|c|}
\hline Nilai & Frekuensi \\
\hline $23-27$ & 4 \\
$28-32$ & 5 \\
$33-37$ & 6 \\
$38-42$ & 7 \\
$43-47$ & 5 \\
$48-52$ & 3 \\
\hline Jumlah & 30 \\
\hline
\end{tabular}

Tabel 3

Hasil Pretes Kelas Kontrol

\begin{tabular}{|c|c|}
\hline Nilai & Frekuensi \\
\hline $20-24$ & 3 \\
$25-29$ & 5 \\
$30-34$ & 6 \\
$35-39$ & 7 \\
$40-44$ & 5 \\
$45-49$ & 4 \\
\hline Jumlah & 30 \\
\hline
\end{tabular}

Tabel 4

Hasil Postes Kelas Eksperimen

\begin{tabular}{|c|c|}
\hline Nilai & Frekuensi \\
\hline $68-72$ & 3 \\
$73-77$ & 5 \\
$78-82$ & 7 \\
$83-87$ & 8 \\
$88-93$ & 5 \\
$94-98$ & 2 \\
\hline Jumlah & 30 \\
\hline
\end{tabular}

Tabel 5

Hasil Postes Kelas Kontrol

\begin{tabular}{|c|c|}
\hline Nilai & Frekuensi \\
\hline $60-64$ & 2 \\
$65-69$ & 5 \\
$70-74$ & 8 \\
$75-79$ & 7 \\
$80-84$ & 5 \\
$85-89$ & 3 \\
\hline Jumlah & 30 \\
\hline
\end{tabular}

Berikut dibawah ini hasil uji normalitas secara keseluruhan dari data yang telah didapatkan:

Tabel 6

Hasil Uji Normalitas

\begin{tabular}{|l|l|l|}
\hline Kelas & $\begin{array}{l}\boldsymbol{x}^{\mathbf{2}} \text { hitung } \\
<\boldsymbol{x}^{\mathbf{2}} \text { tabel }\end{array}$ & Interpretasi \\
\hline $\begin{array}{l}\text { Pretes } \\
\text { eksperimen }\end{array}$ & $1,77<7,82$ & Normal \\
\hline $\begin{array}{l}\text { Pretes } \\
\text { eksperimen }\end{array}$ & $0,72<7,82$ & Normal \\
\hline $\begin{array}{l}\text { Pretes } \\
\text { control }\end{array}$ & $2,09<7,82$ & Normal \\
\hline $\begin{array}{l}\text { Postes } \\
\text { kontrol }\end{array}$ & $0,59<7,82$ & Normal \\
\hline
\end{tabular}

Tabel 7

Hasil Uji Homogenitas

\begin{tabular}{|c|c|c|}
\hline Kelas & $\begin{array}{c}F \text { hitung } \\
<\mathrm{F} \text { tabel }\end{array}$ & Interpretasi \\
\hline $\begin{array}{c}\text { Pretes kelas } \\
\text { eksperimen }\end{array}$ & $\begin{array}{c}1,02< \\
2,09\end{array}$ & Homogen \\
dan kontrol & & \\
\hline $\begin{array}{c}\text { Postes kelas } \\
\text { eksperimen }\end{array}$ & $\begin{array}{c}1,03< \\
2,09\end{array}$ & Homogen \\
dan kontrol & & \\
\hline
\end{tabular}

Tabel 8

Hasil Perbedaan Pretes

\begin{tabular}{|c|c|c|}
\hline Statistik & Eksperimen & Kontrol \\
\hline Rata-rata & 37,16 & 35,20 \\
\hline Varian & 57,69 & 58,57 \\
\hline Jumlah & 30 & 30 \\
\hline
\end{tabular}

Dengan mengambil taraf signifikansi $\alpha=2 \%$ dan $\mathrm{dk}=58$ maka diperoleh $t$ tabel 2,00. Hasil perhitungan didapatkan hasil $t$ hitung $<\mathrm{t}$ tabel $=1,00<2,00$ artinya $H_{o}$ diterima. Dengan diterimanya $H_{o}$ bahwa hasil kedua kelas eksperimen maupun kelas control tidak terdapat perbedaan secara signifikan. 
Tabel 9

Hasil Perbedaan Postes

\begin{tabular}{|c|c|c|}
\hline Statistik & Eksperimen & Kontrol \\
\hline Rata-rata & 82,23 & 74,83 \\
\hline Varian & 51,28 & 49,45 \\
\hline Jumlah & 30 & 30 \\
\hline
\end{tabular}

Dengan mengambil taraf signifikansi $\alpha=2 \%$ dan $\mathrm{dk}=58$ maka diperoleh $t$ tabel 2,00. Hasil perhitungan didapatkan hasil $t$ hitung $<\mathrm{t}$ tabel $=4,04<2,00$ artinya $H_{o}$ ditolak. Dengan ditolak $H_{o}$ bahwa hasil kedua kelas eksperimen maupun kelas kontrol terdapat perbedaan secara signifikan.

\section{KESIMPULAN}

Secara umum, hasil penelitian menunjukkan bahwa hasil kemampuan pemahaman matematis siswa cenderung terdapat peningkatan pada kedua kelas yang di jadikan sampel penelitian. Hasil secara statistika deskriptif terlihat bahwa hasil postes untuk kelas eksperimen yaitu kelas dengan pembelajaran metode investigasi kelompok lebih tinggi di bandingkan dengan kelas control yaitu kelas dengan pembelajaran metode ekspositori. Begitu juga dengan hasil statistik inferensi antara kelas eksperimen dan kelas control berbeda secara signifikan. Penting untuk meningkatkan kemampuan pemahaman matematis siswa, sebagai sarana siswa untuk mempelajari materi-materi matematika yang lebih komplek.

\section{REFERENSI}

Anita, A. (2018). PEMBELAJARAN KOOPERATIF INVESTIGASI KELOMPOK UNTUK MENINGKATKAN HASIL BELAJAR MATEMATIKA SISWA KELAS IX SMP NEGERI 1 TEMBILAHAN. Jurnal Pendidikan, 9(1), 71-83.
Arikunto, S., \& Jabar, C. S. A. (2004). Evaluasi program pendidikan pedoman teoritis praktis bagi praktisi Pendidikan. Jakarta: Bumi Aksara.

Hasanah, A. (2004). Mengembangkan Kemampuan Pemahaman dan Penalaran Matematika Siswa Sekolah Menengah Pertama Melalui Pembelajaran Berbasis Masalah yang Menekankan pada Representasi Matematik. Bandung: Program Pasca Sarjana UPI Bandung.

Isjoni, H. (2013). Cooperative Learning efektifitas pembelajaran kelompok. Bandung: Alfabeta.

Jatisunda, M Gilar. (2017). Hubungan self-efficacy siswa SMP dengan kemampuan pemecahan masalah matematis. Jurnal THEOREMS (The Original Research of Mathematics), 1(2).

Jatisunda, Mohamad Gilar. (2019). Kesulitan Siswa dalam Memahami Konsep Trigonometri di lihat dari Learning Obstacles. Didactical Mathematics, 2(1), 9-16.

Kamalia, F. F., Basir, M. A., \& Ubaidah, N. (2020). Analisis Pemahaman Matematis Siswa pada Materi Trigonometri. IndoMath: Indonesia Mathematics Education, 3(1), 28-35.

Pane, A., \& Dasopang, M. D. (2017). Belajar dan pembelajaran. Fitrah: Jurnal Kajian Ilmu-Ilmu Keislaman, 3(2), 333-352.

Putridayani, I. B., \& Chotimah, S. (2020). ANALISIS KESULITAN BELAJAR SISWA DALAM PELAJARAN MATEMATIKA PADA MATERI PELUANG. MAJU: Jurnal Ilmiah Pendidikan Matematika, 7(1).

Rijanto, M. L. E. J. (2020). KEMAMPUAN PEMAHAMAN MATEMATIS SISWA SMA DENGAN TEAM TEACHING PADA PELAKSANAAN 
PROGRAM PENGENALAN LAPANGAN TAHUN 2015. JPMI (Jurnal Pembelajaran Matematika Inovatif), 3(2), 109-122.

Sariningsih, R. (2014). Pendekatan kontekstual untuk meningkatkan kemampuan pemahaman matematis siswa SMP. Infinity Journal, 3(2), 150-163.

Slavin, R. E. (1980). Cooperative learning. Review of Educational Research, 50(2), 315-342.

Sugiyono, D. R. (2006). Statistika untuk penelitian. Bandung: CV. Alfabeta.

Sukmadinata, N. S. (2005). Metode penelitian pendidikan.

Sutrisno, S. (2015). Analisis Kesulitan Belajar Siswa Kelas II pada Materi Penjumlahan dan Pengurangan Bilangan. AKSIOMA: Jurnal Matematika Dan Pendidikan Matematika, 6(1/Maret).

Yuliani, R. E. (2017). DESAIN SITUASI DIDAKTIS UNTUK MENGANTISIPASI

KECEMASAN MATEMATIKA SISWA PADA PEMBELAJARAN KONSEP ALJABAR DI SEKOLAH MENENGAH PERTAMA. Jurnal Penelitian Pendidikan Matematika, 1(2), 105-120. 